\title{
On the macroeconomic impact of the August 1999 earthquake in Turkey: a first assessment
}

\section{Faruk Selcuk \& Erinc Yeldan}

To cite this article: Faruk Selcuk \& Erinc Yeldan (2001) On the macroeconomic impact of the August 1999 earthquake in Turkey: a first assessment, Applied Economics Letters, 8:7, 483-488, DOI: $10.1080 / 13504850010007501$

To link to this article: https://doi.org/10.1080/13504850010007501

曲 Published online: 06 Oct 2010.

Submit your article to this journal

Џlll Article views: 134

Citing articles: 13 View citing articles 지 


\title{
On the macroeconomic impact of the August 1999 earthquake in Turkey: a first
}

\section{assessment}

\author{
FARUK SELCUK and ERINC YELDAN \\ Department of Economics, Bilkent University, Bilkent, Ankara 06533, Turkey, \\ E-mail:faruk@bilkent.edu.tr,yeldane@bilkent.edu.tr
}

The devastating earthquake that struck the most densely populated and industrialized area of Turkey on 17 August, 1999 was one of the most damaging natural disasters during this century. This paper is a first attempt to estimate the transition path of the Turkish economy to its new equilibrium after the earthquake. An applied general equilibrium model is utilized to provide an initial assessment and to obtain the second best policy options to mitigate the negative effects of the earthquake. The analytical foundations of the model rest upon intertemporal dynamics as laid out in neoclassical growth theory. Simulation results suggest that the initial impact of the earthquake on GDP may range from $-4.5 \%$ to $+0.8 \%$ of GDP, conditional upon policies followed by the government and international donors. The policy implication of the paper is that best outcomes might be reaped via a negative indirect tax (a subsidy financed by foreign aid) to individual sectors to recover their capital losses. On the other hand, an indirect tax to finance the extra fiscal spending would result in an output loss, further deepening the impact of the earthquake on the economy.

\section{INTRODUCTION}

The devastating earthquake that struck the most densely populated and industrialized area of Turkey on 17 August 1999 was one of the most damaging natural disasters to occur during the last quarter of the twentieth century. The earthquake, with a magnitude of 7.4 on the Richter scale, resulted in a calamity over a large area, claiming more than 15400 lives (as of 10 September 1999) and injuring more than 40000 people. Another 5000 were believed to be missing. Furthermore, at least 100000 residential units had collapsed totally, several kilometres of roads were ruined, and the main power transmission network in the region was totally destroyed.

The earthquake brings up many important questions for the Turkish economy: What is the extent of the damage? What are the optimal policies that will allow the most rapid recovery of the physical capital loss? And, given such policies, how will the transition path of the economy evolve during adjustments to the new (long-run) equilibrium? Even though there are numerous estimates in the popular press on the extent and macroeconomic implications of the damage based on hindsight and extrapolation, the authors feel that a theory-based analytical assessment is yet to be provided. This paper is a first attempt to make such an initial assessment on the macroeconomic impact of the earthquake on certain macroeconomic variables from the immediate to the long run. To this end, an applied general equilibrium (GE) model is utilized. ${ }^{1}$

The study's modelling exercises reveal that the initial impact of the earthquake on GDP may range from $-4.5 \%$ to $+0.8 \%$ of GDP, conditional upon the policies followed by the government and the international donors. The major policy implication of the paper is that a negative

\footnotetext{
${ }^{1}$ After we had completed this paper, the State Planning Organization and the World Bank announced their initial assessments. It appears that both studies were conducted under the assumption of what we call 'no policy change' below.
} 
indirect tax (a subsidy financed by foreign aid) to individual sectors to recover capital losses yields the best outcome. On the other hand, an indirect tax to finance extra fiscal expenditures would result in an output loss, further deepening the impact of the earthquake on the economy.

The paper is organized as follows. The GE model and its underlying structure are explained in Section II. Section III reports the main results. Section IV concludes.

\section{THE GENERAL EQUILIBRIUM MODEL}

With some modifications, the model utilized in this study is an extended neoclassical growth model with intertemporally optimizing agents (Blanchard and Fischer, 1989; Barro and Sala-i-Martin, 1995). The antecedents of the current model rest upon the recent contributions in intertemporal general equilibrium modelling by Goulder and Summers (1989), Go (1994), Mercenier and de Souza (1994), Mercenier and Yeldan (1997), and Diao et al. (1998). Data used to calibrate the model parameters and to conduct these simulation experiments are drawn from Kose and Yeldan (1996) and the most recent input-output table of Turkey (SIS, 1994).

Production activities are aggregated into six production sectors (agriculture, consumer manufacturing, producer manufacturing, intermediates, private services, and public services), employing labour and capital to produce their respective single outputs. With a fixed endowment, ${ }^{2}$ labour is mobile across sectors (but not mobile internationally).

The private household owns labour and financial wealth and allocates income to consumption and savings to maximize an intertemporal utility function over an infinite horizon (consumption smoothing a la Ramsey), given market prices and wage remunerations. Physical capital is the only cumulative factor and the economy is open in the sense that the agents have free access to world capital markets at a given interest rate. Technological change is assumed not to be influenced by the policies considered in the paper, and hence is ignored.

The representative firm in each sector carries out both production and investment decisions so as to maximize the value of the firm. In each sector, the firm chooses the level of capital and labour employment to maximize the present value of all future profits, taking into account the expected future prices for sectoral outputs, the wage rate, and the rental rates.

The government has four interrelated functions in the model: to collect taxes, distribute transfer payments, purchase goods and services, and administer domestic public debt. The model distinguishes three types of tax structures. Direct income taxes are set at a given ratio of private income; indirect taxes are levied on the gross output value in each sector; and trade taxes are implemented ad valorem on imports. Basic government spending includes the transfer payments to households, public consumption expenditures (inclusive of wage costs of public employees) and interest costs on outstanding public debt. To avoid the difficulties that would result from modeling the government as an intertemporal optimizing agent (Mercenier and de Souza, 1994), it is assumed that the transfer payments are proportional to aggregate government revenues, while the total public consumption of goods (excluding public services) is set as a constant share of the gross domestic product. Similarly, sectoral purchases are distributed given fixed expenditure shares.

Following the traditional CGE folklore, the model incorporates the Armingtonian composite good system for the determination of imports, as well as the constant elasticity of transformation (CET) specification for exports. In this structure, domestically produced and foreign goods are regarded as imperfect substitutes in aggregate demand, given an elasticity of substitution/transformation. The economy is small, hence world prices are regarded as given constants. However, composite prices do change endogenously as domestic prices adjust to attain equilibrium in the commodity markets. In each periodequilibrium, the difference between household savings and aggregate investment gives the amount of new foreign bonds held by households. The time path of private foreign assets has two components: trade surplus (or deficit) and interest income received from the accumulated foreign assets (or interest payments to accumulated foreign liabilities).

An intra-temporal equilibrium requires that at each time period, (i) domestic demand plus foreign demand for the output of each sector equals its supply; (ii) producers' labour demand equals total labour supply; (iii) the gap in aggregate investment and domestic savings equals foreign deficit and is covered by foreign borrowing; and (iv) government spending equals government revenues plus new issues of public debt instruments.

The inter-temporal equilibria are further constrained by additional steady state conditions warranting that (i) the value of firms should become constant and hence the profits simply equal the interest earnings from the same amount of riskless assets; (ii) in each sector, investments just cover the depreciation of sectoral capital; hence the capital stock remains constant; and (iii) foreign asset holding is constant, implying that the economy has to have a surplus on its trade balance to pay off the interest payments on its foreign debt.

As for the implementation of the model for policy analysis, the following restrictive assumption is made: it is

\footnotetext{
${ }^{2}$ This specification has no real effects on the model since, alternatively, all variables in per capita terms could be normalized.
} 
Table 1. The share of core earthquake zone in Turkey's manufacturing sector

\begin{tabular}{lll}
\hline Province & Output share & Employment share \\
\hline Kocaeli & 15.3 & 5.1 \\
Sakarya & 0.8 & 1.2 \\
Yalova & 0.8 & 0.6 \\
Total & 16.9 & 6.9 \\
\hline
\end{tabular}

Source: The State Institute of Statistics.

assumed that only $10 \%$ of the existing capital stock and only $15 \%$ of the employed labour force in the core quake area are damaged permanently. The author's are aware that there is an inevitable fall in overall productivity in the region, as well as in other parts of the economy. However, this study does not make any further assumptions on the possible rate effects on the production technology, and the analysis is limited to the discussion of the Rybczynski-like level effects. Therefore, the results should be viewed as a 'conservative estimate' of the possible losses caused by the earthquake disaster.

Table 1 lists the share of the core earthquake region in the country's total manufacturing. The output share of the region in total manufacturing production is $16.9 \%$. Given the absence of reliable estimates of capital stock for Turkey, it is assumed that the proportion of the capital stock in this region is directly reflected in its output share. Therefore, assuming a 10\% loss in the capital stock of this region implies a 1.7\% capital loss in the aggregate economy.

The employment share of the region in manufacturing industry is $6.9 \%$. A conservative $15 \%$ loss in employment in this region as a result of the earthquake implies a $1.03 \%$ decline in employment in the national economy. Therefore, a $1 \%$ fall in overall employment was further assumed in these calculations.

\section{RESULTS}

This paper studies four issues and conducts four simulations under alternative assumptions: (i) no policy change; (ii) reliance on indirect taxes to finance the extra government expenditures for public investments to replenish the losses in the capital stock; (iii) endogenous adjustments on the existing indirect tax rates to recover the loss in the capital stock; and (iv) invigoration of foreign aid to recover the capital loss.

\section{No policy change}

Figure 1 presents the adjustments of GDP, consumption, investment, external deficit, and private sector foreign
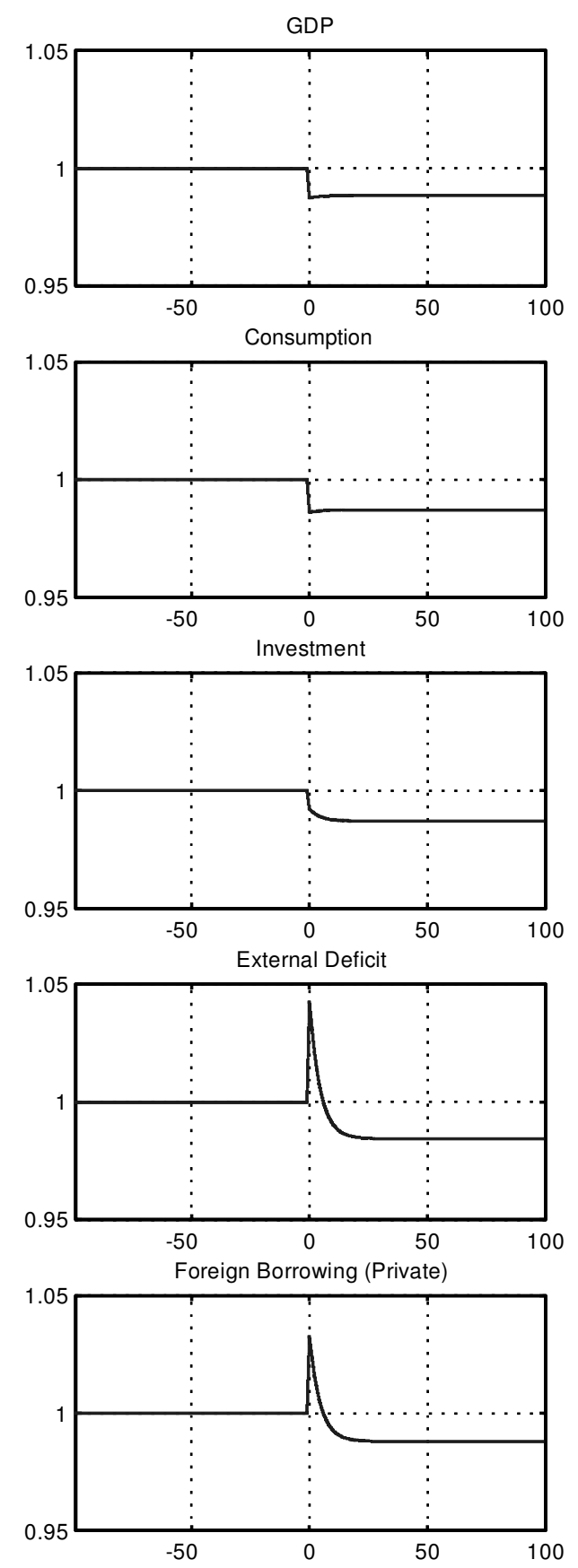

Fig. 1. The effect of the earthquake (no policy change)

borrowing under the assumption that there is no policy change in the economy following the earthquake.

It is found that the effect of the earthquake is a $1.3 \%$ decline in GDP on impact. The aggregate value-added recovers slightly and converges to $1.2 \%$ less than its initial base path. In a present value sense, this corresponds to $26 \%$ of the long-run equilibrium (steady state) value of the total GDP. ${ }^{3}$ Similarly, total consumption goes down

\footnotetext{
${ }^{3}$ If a $5 \%$ discount rate is assumed, this amounts to 52 billion US dollars at 1998 prices.
} 
by $1.4 \%$ on impact and converges to a level $1.3 \%$ less than its initial path. On the other hand, aggregate investment first decreases by $0.8 \%$ and converges to $1.3 \%$ less than its initial base path.

The earthquake causes an immediate $4.2 \%$ increase in external deficit. Since a 'no-Ponzi game' condition in the model was proposed, the calculations show that the economy must give an external surplus of $1.6 \%$ more than what it would have given before the earthquake. ${ }^{4}$ The initial external deficit is partially financed by private sector foreign borrowing (PSFB). It is seen that PSFB increases by $3.3 \%$ after the earthquake and converges to $1.2 \%$ negative borrowing at the new steady state.

\section{Discretionary adjustments on indirect tax rates}

Next, an active government is modelled, which aims at a recovery of the losses in the aggregate capital stock. For this purpose it is assumed that the government imposes an additional indirect tax at the rate of $1 \%$ in all sectors to finance its additional investments. ${ }^{5}$ Figure 2 plots the time path of the variables after the tax.

It is found that the indirect tax magnifies the impact of the earthquake disaster on the economy. In this case there is a $4.5 \%$ decline in GDP from its initial base run. This clearly results from the distortionary nature of indirect taxation, causing a divergence of domestic relative prices from their efficiency counterparts. The worsening effect reveals itself the most under long run equilibrium. It is seen that GDP converges to $5.8 \%$ below its initial path. The indirect tax has also significant adverse effects on aggregate investment. Aggregate investment falls immediately by $18 \%$. Under the new long run equilibrium, it is $12 \%$ less than its initial base path. On the other hand, the total consumption responds in a very sluggish manner to the tax. An initial $0.8 \%$ decline in consumption is followed by a permanent fall of $1.9 \%$. It can be concluded that the indirect tax has strong crowding out effects on total investment. The external deficit is reduced by $48 \%$, causing a $47 \%$ decline in PSFB at impact.

\section{Flexible indirect tax adjustments to recover the capital loss}

In this part, a flexible indirect tax is introduced aiming to recover fully the initial capital loss caused by the earthquake. Technically, an additional constraint is set that the capital stock loss has to be fully recovered, and an endogenous adjustment rate on indirect taxes is introduced as a slack variable serving as the shadow price of this constraint. Labour characteristics of the model are relied on to
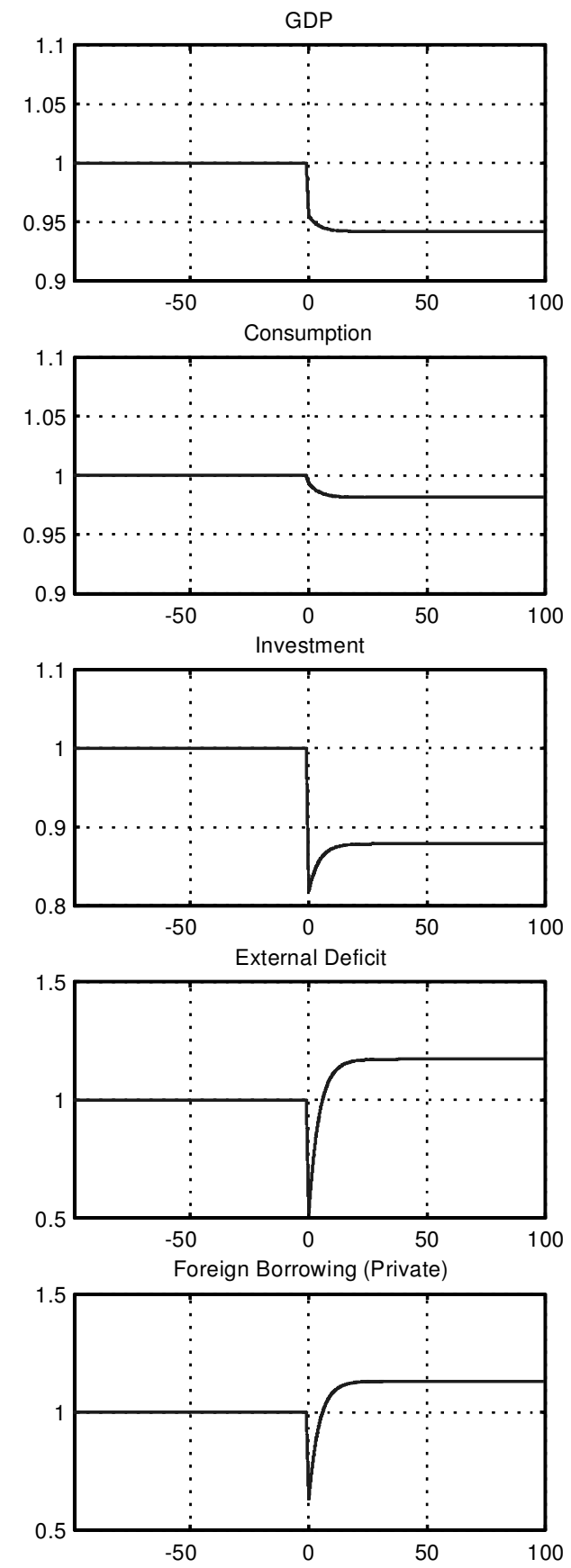

Fig. 2. The effect of indirect taxation

solve for the necessary adjustment. The results are given in Figure 3. The capital loss recovering adjustment of the indirect tax turns out to be negative 3.3\% upon impact, and is gradually phased out. This implies that the government should give an instantaneous 3.3\% tax break to all

\footnotetext{
${ }^{4}$ Here it is assumed that the economy already has a stock of foreign liabilities.

${ }^{5}$ This scenario formally matches the policy discussions within the Finance Ministry. It is reported that a one percentage point increase in the value added tax is being debated to countervail the expected burden on the budgetary outlays. Note that the scenario here goes one step further, and directs the proceeds of the tax only to fund capital investment by the public sector.
} 

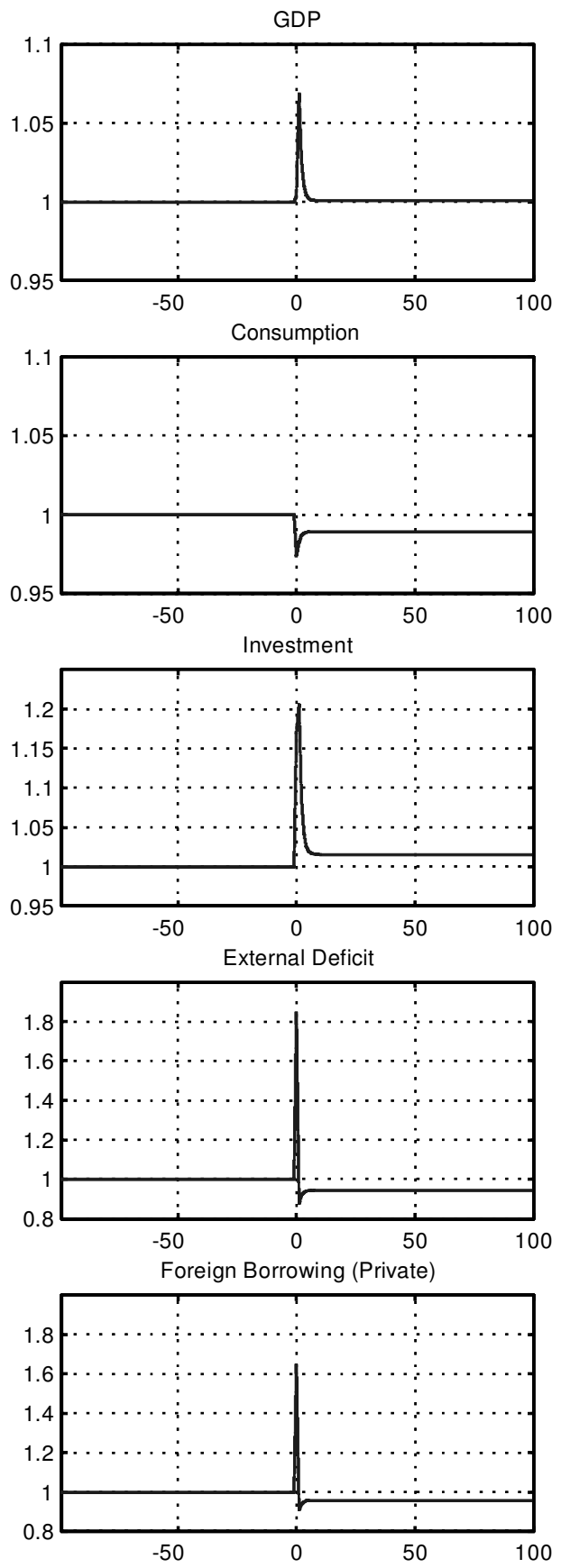

Fig. 3. The effect of indirect taxation on recovery of capital loss

sectors. It is found total GDP in the economy does not change significantly (a $0.4 \%$ increase on impact and $0.08 \%$ increase permanently). However, total consumption falls by $2.7 \%$ initially. The long-run equilibrium indicates a permanent decrease of $1.1 \%$ in consumption in comparison with the initial base path. It is therefore concluded that a capital-loss-recovering subsidy is still associated with a welfare loss although the output is back to its initial base path.

The results further indicate that aggregate domestic investment expenditures have to be increased by $17 \%$
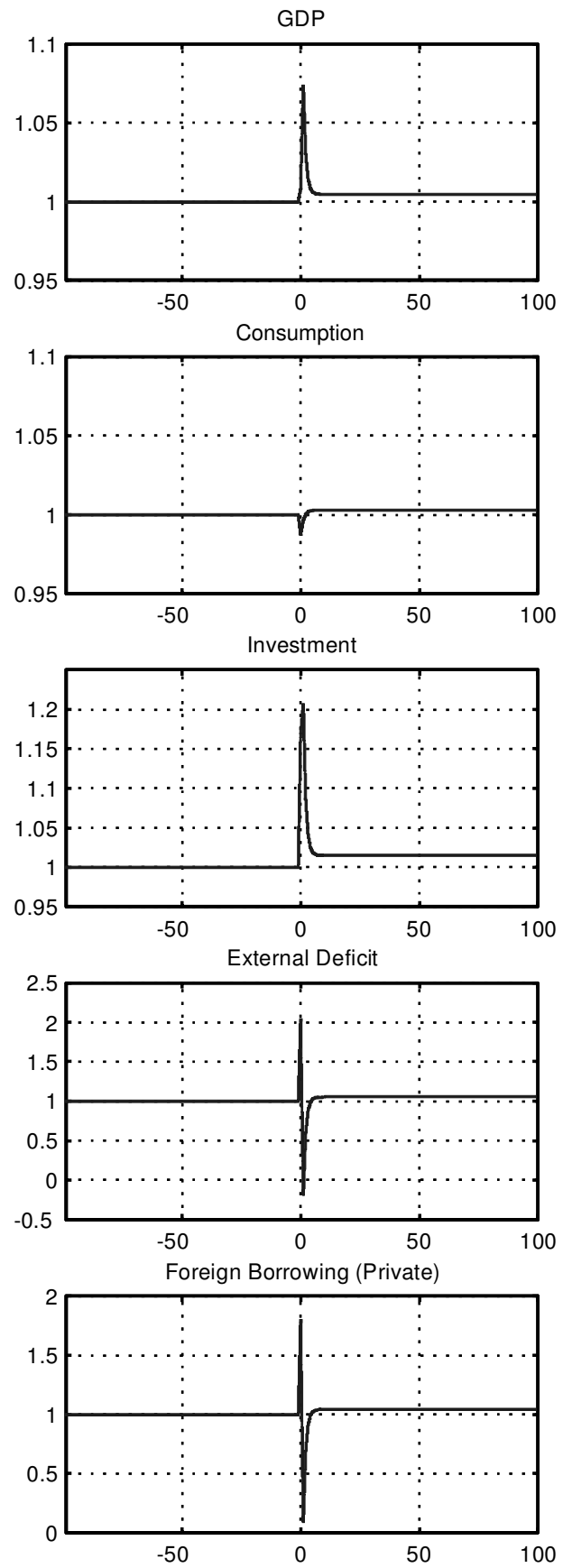

Fig. 4. The effect of foreign aid on recovery of capital loss

after the earthquake, converging later to $1.6 \%$ above its initial path. The external deficit and PSFB are up by 84 and $65 \%$, respectively, at the beginning. In other words, the economy finances the capital loss mainly by foreign borrowing.

\section{Foreign aid to recover capital loss}

The final exercise asks the following question: How would the economy adjust if the capital recovering indirect 
tax (subsidy) is financed by foreign aid and how much foreign aid amount be required for this? The results are given in Figure 4. The only difference between the previous exercise (a subsidy to all sectors financed endogenously) and this case is in consumption. Although the total consumption falls by $1.3 \%$ at the beginning, it reverses itself immediately and converges to $0.3 \%$ above its initial path. This case is the only one in which the welfare loss is fully compensated following the earthquake. The total foreign aid required to put the economy on its pre-earthquake path is calculated to be $5.6 \%$ of total GDP upon impact (11 billion US dollars at 1998 prices), to be followed by reduced inflows amounting to $2.2 \%$ in Period 2, and $1.1 \%$ in Period 3, then gradually stabilizing at $0.4 \%$.

\section{CONCLUSION}

This paper has attempted an initial assessment of the possible effects of the massive 17 August earthquake in Turkey on the macroeconomic balances of the country. Utilizing an intertemporal GE apparatus, this paper tried to obtain estimates of the extent of the damage on the domestic macrobalances and seek out viable policy lessons for recovery. Starting from very conservative assumptions on the loss of aggregate capital stock and employment, and ignoring likely negative effects on productivity, it was found that the initial impact of the earthquake on GDP may range from $-4.5 \%$, to $+0.8 \%$, conditional upon the policy stance of the government and the international community. One major finding of this analysis is that the currently debated increase in indirect tax rate to fund the increased public expenditure is likely to generate further contractionary effects on the already distorted economy, deepening the impact of the crisis. It was also found that a policy of production subsidy to individual sectors financed by foreign aid to recover the capital loss yields the best outcome from the viewpoint of consumer welfare.

\section{ACKNOWLEDGEMENTS}

The author's are grateful to Neil Arnwine, Merih Celasun, Ramazan Gencay, Jean Mercenier, Murat Sertel and colleagues at Bikent University for their encouragement and most valuable comments at various stages of this study. Needless to assert, none of them bears any responsibility for the propositions and conclusions advanced in this paper.

\section{REFERENCES}

Barro R. J. and Sala-i-Martin, X. (1995) Economic Growth, McGraw Hill, New York.

Blanchard, O. J. and Fischer, S. (1989) Lectures on Macroeconomics, MIT Press, Cambridge, MA.

Diao, R. and Yeldan, E. (1998) Fiscal debt management, accumulation and transition dynamics in a CGE model for Turkey, Canadian Journal of Development Studies, 19, 343-76.

Go, D. S. (1994) External shocks, adjustment policies, and investment in a developing economy: illustrations from a forward-looking CGE model of the Philippines, Journal of Development Economics, 44, 229-61.

Goulder, L. and Summers, L. (1989) Tax policy, asset prices, and growth: a general equilibrium analysis, Journal of Public Economics, 38, 265-96.

Kose, A. and Yeldan, E. (1996) Cok Sektorlu Genel Denge Modellerinin Veri Tabani Uzerine Notlar: Turkiye 1990 Sosyal Hesaplar Matrisi, METU Studies in Development, 23, 59-83.

Mercenier J. and da C. S. de Souza, M. (1994) Structural adjustment and growth in a highly indebted market economy: Brazil, Applied General Equilibrium Analysis and Economic Development (Eds.) J. Mercenier and T. Srinivasan, University of Michigan Press, Ann Arbor.

Mercenier J. and Yeldan, E. (1997) On Turkey's trade policy: is a customs union with Europe enough? European Economic Review, 41, 871-80.

State Institute of Statistics (SIS) (1994), The 1990 Input-Output Structure of Turkey, SIS Publications, Ankara. 